\title{
Toxicity Studies on Leaf Extracts of Alternanthera brasiliana (L.) Kuntze and Alternanthera bettzickiana (Regel) Voss
}

\author{
Kasthuri O R ${ }^{1 *}$, Ramesh B ${ }^{2}$ \\ ${ }^{1}$ Assistant Professor, Department of Biochemistry, Navarasam Arts and Science College for Women, Arachalur, Erode 638101, Tamilnadu, India. \\ ${ }^{2}$ Associate Professor, Department of Biochemistry, PSG College of Arts and Science, Coimbatore 641014, Tamilnadu, India.
}

\begin{tabular}{l}
\hline ARTICLE INFO \\
\hline Article history: \\
Received on: 03/06/2018 \\
Accepted on: $13 / 08 / 2018$ \\
Available online: $31 / 10 / 2018$
\end{tabular}

\section{Key words:}

Cytotoxicity, $\mathrm{LD}_{50}$,

hematology, MTT assay,

histopathology.

\begin{abstract}
Herbal medicine is the source for the search of many novel therapeutic compounds in developing countries. Before used as medicine, drugs from plant origin must be ensured as safe. Objective: The present work focused to study the in vivo and in vitro toxicity effects of hydroethanolic leaf extracts of Alternanthera brasiliana (A. brasiliana) and Alternanthera bettzickiana (A. bettzickiana). Methods: Sub-acute toxicity studies of hydroethanolic leaf extracts of $A$. brasiliana and $A$. bettzickiana were carried out in vivo on mice. 11 groups of albino mice were treated with five different doses of the hydroethanolic leaf extracts of A. brasiliana and A. bettzickiana orally for 14 days. General appearance and behavior were observed for 14 consecutive days. Effect on hematological parameters and histopathological changes were also monitored. Cytotoxicity was assessed by observing its toxicity in vitro against DLA cell line by using MTT assay. Results: Sub-acute toxicity studies results showed that up to the tested dose of $2000 \mathrm{mg} / \mathrm{kg}$ bwt in both extract treatments, throughout the 14 days of treatment, the extract does not produced any toxicity symptoms. MTT assay indicated that both leaf extracts exhibited significant concentration-dependent in vitro cytotoxic activity against DLA cell line. Hydroethanolic leaf extract of $A$. bettzickiana exhibited more potent cytotoxic effects on DLA cells than A. brasiliana extract. Conclusion: No toxicity related symptoms were observed in different doses of leaf extract treated mice groups. So the $\mathrm{LD}_{50}$ values of the tested leaf extracts were more than $2000 \mathrm{mg} / \mathrm{kg}$ bwt.
\end{abstract}

\section{INTRODUCTION}

Cancer is considered to be one of the most dreaded diseases. Uncontrolled cell proliferation or metastasis of abnormal cells in the body results in cancer (Kaufman and Chabner, 1996). Cancer is found to be one of the major factor causing mortality. More than one-third of the world's population is affected by cancer. It accounts for more than $20 \%$ of all deaths. Causes of cancer include tobacco, viral infection, chemicals, radiation, environmental factors, and dietary factors (Lemkebthomas et al., 2008). At present, the common treatment strategies in cancer are the use of chemotherapeutic agents, surgery, and radiation. These treatments are not fully effective and cause many side effects. Hence, there is a great interest to develop safe and low cost anticancer agents from natural sources (Moongkarndi et al., 2004).

${ }^{*}$ Corresponding Author

Kasthuri OR, Assistant Professor of Biochemistry, W/O Baraneedaran, 138 Paruvachi, Bhavani Erode(dt)-638312, Tamilnadu, India.

E-mail: kasthure@gmail.com
Since 1950, a vast number of plant-derived agents are used to treat cancer (Kinzler and Vogelstein, 2002). Plants contain a large profile of secondary metabolites that are mainly responsible for their cytotoxic activity. In the development of anti-cancer agents, the isolation of vincristine and vinblastine from vinca and podophyllotoxins from Podophyllumhexandrum are considered as milestones (Newman et al., 2003). Various traditional herbal medicines are used by a majority of the people in developing countries to treat a number of diseases and ailments (Liu, 2011). Herbal based medications are often considered to be safe as they are natural and free from side effects (Lopes et $a l ., 2000)$. The increase in the popularity of herbal remedies and the limited number of scientific works on their safety and efficacy, toxicity and adverse effects related to herbal remedies are widely recognized (Saad et al., 2006). There are growing evidence that support the toxicity of herbal medicines towards their users. Though various studies of the pharmacological potential of medicinal plants have been carried out in the past, 
works investigating their potential toxicities are very limited (Wojcikowski et al., 2004).

No drug should be used clinically without its clinical trials and toxicity studies (Anisuzzaman et al., 2001). Sub-acute oral toxicity studies of herbal medicines are essential to identify the safety and the determination of dose level that could be used subsequently. It also helps in the investigation of the therapeutic index of drugs and xenobiotics (Rang et al., 2001).

$A$. brasiliana and $A$. bettzickiana were herbaceous plants belonging to the family Amaranthaceae. Amaranthaceae family consists of 64 genera and about 800 species, represented by herbs and shrubs. This cosmopolitan family is most abundant in tropical regions of Africa, India, and America (Hussien, 2005). The leaves of $A$. brasiliana are most widely used for therapeutic applications. The phytochemical constituents reported in this plant are flavonol glycosides (3-O-robinobioside derivatives of kaempferol and quercetin), vitamins (riboflavin and niacin), betacianin and steroids such as $\beta$-sitosterol (Kumar et al., 2011). The whole plant of $A$. bettzickiana was useful in nourishing and purifying the blood, as a soft laxative, as antipyretic, as a galactagogue and also had wound healing property. Studies in the liver of ovariectomized mice showed the potential of $A$. bettzickiana in improving superoxide dismutase and catalase activities (Suphanthip et al., 2013).

In our preliminary study, phytochemical constituents and in vitro antioxidant potentials of $A$. brasiliana and $A$. bettzickiana were carried out (Kasthuri and Ramesh, 2018). The current work, sub-acute toxicity study is formulated to find out the safe dose level and $\mathrm{LD}_{50}$ values of hydroethanolic leaf extracts of $A$. brasiliana and $A$. bettzickiana in swiss albino mice model. The leaf extracts were also screened in vitro for cytotoxic activity against DLA cell line using MTT assay.

\section{MATERIALS AND METHODS}

\section{Plant materials and extraction}

The healthy leaves of $A$. brasiliana and A. bettzickiana were collected from SKM Siddha and Ayurvedha, Erode. The plants were identified and authenticated at Botanical Survey of India, Coimbatore with voucher number BSI/SRC/5/23/2015/Tech/100 for Alternanthera brasiliana (L). Kuntze - AMARANTHACEAE and BSI/SRC/5/23/2015/Tech/101 for Alternanthera bettzickiana (Regel) Voss - AMARANTHACEAE. The leaves of $A$. brasiliana and $A$. bettzickiana were separately washed, shade dried and was coarsely powdered using a mechanical grinder. The shade dried coarsely powdered leaf samples of $(500 \mathrm{~g})$ A. brasiliana and $A$. bettzickiana were extracted with hydroethanol by using hot continuous percolation process (Soxhlet). The leaf extracts were concentrated by using a rotary vacuum evaporator (Buchi) at $50^{\circ} \mathrm{C}$, dried in a vacuum dessicator and stored at $-20^{\circ} \mathrm{C}$ till further use.

\section{Sub-acute toxicity studies}

The in vivo sub-acute toxicity studies of Alternanthera leaf extracts were conducted according to OECD guideline 423 which stipulate the use of only three animals (Jonsson et al., 2013). Male swiss albino mice weighing $(25 \pm 2) \mathrm{g}$ were used to observe the sub-acute toxicity. Swiss albino mice deprived of food for 18 $\mathrm{hrs}$, were administered with different doses of hydroethanolic leaf extracts of $A$. brasiliana and A. bettzickiana ranging from 100 to
$2000 \mathrm{mg} / \mathrm{kg}$ bwt, orally once a day for 14 days. 11 groups of mice were used to study the acute toxicity and each group consisting of 3 mice as per the Institutional Animal Ethical Committee (IAEC) Proposal No: SVCOP/IAEC/013/2016-17 dt 10.03.2017.

\section{EXPERIMENTAL GROUPS}

Group I: Normal control mice

Group II: Mice fed orally with $100 \mathrm{mg} / \mathrm{kg}$ bwt of $A$. brasiliana leaf extract for 14 days.

Group III: Mice fed orally with $250 \mathrm{mg} / \mathrm{kg}$ bwt of $A$. brasiliana leaf extract for 14 days.

Group IV: Mice fed orally with $500 \mathrm{mg} / \mathrm{kg}$ bwt of $A$. brasiliana leaf extract for 14 days.

Group V: Mice fed orally with $1000 \mathrm{mg} / \mathrm{kg}$ bwt of $A$. brasiliana leaf extract for 14 days.

Group VI: Mice fed orally with $2000 \mathrm{mg} / \mathrm{kg}$ bwt of $A$. brasiliana leaf extract for 14 days.

Group VII: Mice fed orally with $100 \mathrm{mg} / \mathrm{kg}$ bwt of $A$. bettzickiana leaf extract for 14 days.

Group VIII: Mice fed orally with $250 \mathrm{mg} / \mathrm{kg}$ bwt of $A$. bettzickiana leaf extract for 14 days.

Group IX: Mice fed orally with $500 \mathrm{mg} / \mathrm{kg}$ bwt of $A$. bettzickiana leaf extract for 14 days.

Group X: Mice fed orally with $1000 \mathrm{mg} / \mathrm{kg}$ bwt of $A$. bettzickiana leaf extract for 14 days.

Group XI: Mice fed orally with $2000 \mathrm{mg} / \mathrm{kg}$ bwt of $A$. bettzickiana leaf extract for 14 days.

On the evaluation of acute toxicity, all groups of mice treated separately with hydroethanolic leaf extracts of $A$. brasiliana and $A$. bettzickiana were monitored during the entire study period for the signs and symptoms of toxicity and/or mortality, behavioral alterations, food and water intake and changes in body weight. Blood samples were collected after $24 \mathrm{hrs}$ of the last dose of hydroethanolic leaf extracts for the analysis of hematological parameters. On day 14, the mice in each group were sacrificed by cervical dislocation, a small portion of the liver sample was fixed in $10 \%$ formalin for the analysis of histopathological architecture.

\section{Estimation of hematological profile}

The hematological parameters such as hemoglobin, $\mathrm{PCV}, \mathrm{WBC}, \mathrm{RBC}$, and platelets were estimated. The whole blood sample was analyzed using SYSMEX Xs - 800i automatic hematology analyzer.

\section{In vitro cytotoxicity - MTT assay}

MTT assay was employed to study the in vitro cytotoxicity of hydroethanolic leaf extracts of $A$. brasiliana and A. bettzickiana.

\section{MTT assay}

MTT[3-(4,5 dimethylthiazol-2-yl)-2,5-diphenyltetrazolium Bromide] assay has been used widely for testing the in vitro chemosensitivity of tumor cell lines. The assay is based on the principle that only metabolically active cells can reduce the watersoluble MTT salt to its formazan product. The dead cells do not interfere with MTT absorbance levels (Mosmann, 1983).

In living cells, the mitochondrial enzyme succinate dehydrogenase reduces the yellow colored water-soluble substrate 
MTT into an insoluble purple colored formazan product which can be measured spectrophotometrically. MTT assay depends on the mitochondrial activity per cell and number of cells present. MTT reduction can take place only in metabolically active cells and the level of activity is a measure of the viability of the cells (Wilson and John, 2000).

\section{Cell line}

The DLA cell line was purchased from amala cancer research institute, Thrissur, kerala and it was grown in Eagles Minimum Essential Medium containing 10\% fetal bovine serum (FBS). The cells were maintained at $37^{\circ} \mathrm{C}, 5 \% \mathrm{CO}_{2}$, $95 \%$ air and $100 \%$ relative humidity. Weekly, the maintenance cultures were passaged and the culture medium was changed twice per week.

\section{Cell treatment procedure}

Single cell suspensions were made by detaching the monolayer cells with trypsin-ethylene diamine tetra acetic acid (EDTA). Using a hemocytometer, the number of viable cells were counted and are diluted with the medium containing 5\% FBS to attain a final density of $1 \times 10^{5}$ cells $/ \mathrm{ml}$. Cell suspension was seeded into 96-well plates at a plating density of 10,000 cells/well and incubated for $24 \mathrm{hrs}$ at $37^{\circ} \mathrm{C}, 5 \% \mathrm{CO}_{2}, 95 \%$ air and $100 \%$ relative humidity to allow for cell attachment. After incubation, the medium on cells was removed and treated with different concentrations $(12.5,25,50,100$ and $200 \mu \mathrm{g} / \mathrm{ml})$ of $A$. brasiliana and $A$. bettzickiana leaf extracts. The cells were further incubated at $37^{\circ} \mathrm{C}$ in a $5 \% \mathrm{CO}_{2}$ incubator for 5 days. To each well, $30 \mu \mathrm{l}$ of MTT (stock solution of $5 \mathrm{mg} / \mathrm{mL}$ in phosphate-buffered saline) was added and the plates were incubated for $4 \mathrm{hrs}$ at $37^{\circ} \mathrm{C}$. The medium was carefully removed by aspiration and the MTT crystals were dissolved into formazan by the addition of $50 \mu \mathrm{L}$ of DMSO to each well. The absorbance, proportional to the amount of MTT reduced, was measured at $570 \mathrm{~nm}$ using a microplate reader (Versamax). By using a linear regression equation, the $\mathrm{LD}_{50}$ values were calculated with the concentration of Alternanthera leaf extracts that resulted in a 50\% reduction in absorbance when compared to that of untreated cells. $\mathrm{LD}_{50}$ values are expressed as the mean of three independent triplicate assays and values were expressed as mean of quadruplicate assays.

\section{Statistical analysis}

Results of the current study were expressed as mean \pm SD. The statistical significance $(p<0.05)$ between experimental groups were determined using one-way analysis of variance (ANOVA) and post hoc least-significant difference (LSD) test using SPSS version 17.0.

\section{RESULTS AND DISCUSSION}

For the prevention and treatment of various ailments that affect humans, there was a continuous search for new leads from plants and traditional foods. Medicinal plants constitute a realistic and promising anticancer therapeutics (Yan-Wei et al., 2009). Agents from phytotherapeutic products are many times, mistakenly believed to be safe as they are natural (Gesler, 1992). But there are evidence that these products contain several bioactive principles that had the potential to cause adverse toxic effects (Bent and Ko, 2004). Paracelsus, known as the father of toxicology stated that "All substances are poisons; there is none which is not a poison. It is the right dose that differentiates a remedy from poison" (Hunter, 2008).

\section{Sub-acute oral toxicity studies}

Appropriate animal is used as models in toxicity studies. These animal models are commonly used to assess the potential health risks in humans (Schulz et al., 2001). Determination of sub-acute oral toxicity is the first step in the screening and evaluation of toxic potentials of pharmacological compounds (Akhila et al., 2007). The assessment of the toxic nature of plant extracts is useful to define the intrinsic toxicity of the plants and the effects of an acute overdose. It was also indispensable to consider a treatment as safe. Mice are sensitive to toxic components present in plants. The dosing of the plant extracts in increasing amounts helps to evaluate the toxicity limits (Parra et al., 2001).

Sub-acute toxicity studies using animal models provide important preliminary data that helps to select natural remedies with potential health benefits for future work (Rosenthal and Brown, 2007). Toxicity effects of natural remedies in animals and humans are analyzed using some physiological parameters like behavior, body weight, food intake, biochemical, hematological and histological analysis (Ahmad et al., 2013).

\section{General appearance and behavioral observations}

The clinical signs and symptoms exerted by drugs on vital body organs are considered as principal observations among toxicity indicators (Subramanion et al., 2011). On the 14 days treatment with the different doses of Alternanthera leaf extract, the mice in all groups were survived throughout the entire study period. No treatment-related toxic symptoms or mortality were observed after oral administration of various doses of $A$. brasiliana and $A$. bettzickiana leaf extracts. None of these mice had shown any abnormal behavioral responses in any dose range. There was no change in behavior, body weight, temperature, food intake and water consumption, skin effects, fur coating, eyes, mucus membranes and respiratory activities when compared to control group (Table 1).

No major differences were observed between control and different doses of Alternanthera leaf extract treated groups. However, sedation and drowsiness were observed in 1000 and $2000 \mathrm{mg} / \mathrm{kg}$ bwt treated groups of the two studied leaf extracts. Any pharmaceutical drug or compound with the oral $\mathrm{LD}_{50}$ higher than $1000 \mathrm{mg} / \mathrm{kg}$ bwt could be considered safe and low toxic. Oral $\mathrm{LD}_{50}$ values for sub-acute toxicity as per OECD are as follows: $<5 \mathrm{mg} / \mathrm{kg}$ bw - very toxic, $>5<50 \mathrm{mg} / \mathrm{kg}$ bw - toxic, $>50<500 \mathrm{mg} /$ $\mathrm{kg}$ bwt - harmful and $>500<2000 \mathrm{mg} / \mathrm{kg}$ bwt - no label (Walum, 1998).

Following the administration of different doses of hydroethanolic leaf extracts of $A$. brasiliana and $A$. bettzickiana, there was no noticeable change in food and water intake. This showed that the oral administration of leaf extracts did not induce any suppression in appetite and had no deleterious effect on food and water intake. This indicated that the metabolism of carbohydrate, protein, and fat are not affected (Klaassen, 2001). 
Kasthuri and Ramesh / Journal of Applied Pharmaceutical Science 8 (10); 2018: 082-089

Table 1: General appearance and behavioral observations for control and A. brasiliana and A. bettzickiana leaf extracts treated groups.

\begin{tabular}{|c|c|c|c|c|c|c|c|c|c|}
\hline Observation & Body Wt & Temp & Food intake & Breathing & Change in skin & Drowsiness & Sedation & Coma & Alive/Death \\
\hline Group I (Control) & Normal & Normal & Normal & Normal & No effect & Not present & Not present & Not present & Alive \\
\hline Group II & Normal & Normal & Normal & Normal & No effect & Not present & Not present & Not present & Alive \\
\hline Group III & Normal & Normal & Normal & Normal & No effect & Not present & Not present & Not present & Alive \\
\hline Group IV & Normal & Normal & Normal & Normal & No effect & Not present & Not present & Not present & Alive \\
\hline Group V & Normal & Normal & Normal & Normal & No effect & Present & Observed & Not present & Alive \\
\hline Group VI & Normal & Normal & Normal & Normal & No effect & Present & Observed & Not present & Alive \\
\hline Group VII & Normal & Normal & Normal & Normal & No effect & Not present & Not present & Not present & Alive \\
\hline Group VIII & Normal & Normal & Normal & Normal & No effect & Not present & Not present & Not present & Alive \\
\hline Group IX & Normal & Normal & Normal & Normal & No effect & Not present & Not present & Not present & Alive \\
\hline Group X & Normal & Normal & Normal & Normal & No effect & Present & Observed & Not present & Alive \\
\hline Group XI & Normal & Normal & Normal & Normal & No effect & Present & Observed & Not present & Alive \\
\hline
\end{tabular}

No mortalities were observed after the administration of leaf extracts up to the administered dose level of $2000 \mathrm{mg} / \mathrm{kg}$ bwt. This showed that the leaf extracts had a negligible level of toxicity when administered orally to mice. Similar results were found for oral dose administration of P. longifolia extracts in mice (Nair et al., 2009). As there were no observable changes in the general appearance and behavior of control and extract treated groups, the hydroethanolic leaf extracts of $A$. brasiliana and $A$. bettzickiana were found to be safe at the dose level of up to $2000 \mathrm{mg} / \mathrm{kg}$ bwt. Therefore, the $\mathrm{LD}_{50}$ value for both leaf extracts were considered to be $>2000 \mathrm{mg} / \mathrm{kg}$ bwt. This indicated that the oral administration of Alternanthera leaf extracts could be considered relatively safe.

\section{Effect on hematological parameters}

In animal toxicity studies, analysis of blood parameters were important to report any alterations and also to evaluate the relative risk effects on the hematopoietic system when interpreting those findings to human beings (Jothy et al., 2011). The mechanisms of toxicity of a therapeutic agent could be studied by analyzing the biochemical profile and examining its major toxic effects on tissues like liver (Yamthe et al., 2015). Estimation of blood profile parameters like haemoglobin, total red blood cell (RBC), white blood cell (WBC), packed cell volume (PCV) and platelet counts are an important indexes in evaluating the physiological and pathological status of man and animals (Schalm et al., 1975). Intake of some toxic plants results in an alteration in the normal level of these parameters (Ajagbonna et al., 1999). Studies on blood profile provides important information about abnormalities in metabolic processes and the response of the body towards injury or lesion, deprivation and stress (Bosco et al., 2014). Therefore, the haematological parameters can serve as an index to study the extent of the toxic effect of plant extracts (Raza et al., 2002). When the data are translated from animal studies, the changes in haematological status have higher predictive value for human toxicity (Olson et al., 2000). For the diagnosis of the root cause of any disease, the level of haematological index was the important factor. Changes in blood profiles may be due to changes in cellular integrity, cellular membrane permeability or due to exposure to toxic chemicals (Hoffbrand and Pettit, 1997).

Environmental pollutants or toxic stress results in physiological changes that affect the hematological parameters of animals (Jain et al., 2009). In the present study, all the tested hematological parameters (hemoglobin, packed cell volume, white blood cell, red blood cell and platelets count) were within normal limits when compared to the control group. No significant differences $(P>0.05)$ between $A$. brasiliana and $A$. bettzickiana extract treated mice groups and control were found (Table 2).

The level of hemoglobin was found to be $14.6 \mathrm{~g} \%$ in the control group. In A. brasiliana and A. bettzickiana extract treated groups, the level was found to vary between $14.0 \mathrm{~g} \%$ to $14.7 \mathrm{~g} \%$. Control group showed a packed cell volume of $43.9 \%$, whereas A. brasiliana and $A$. bettzickiana extract treated groups showed a maximum level of $44 \%$ and a minimum level of $41.7 \%$. The RBC count was found to be $5.610^{12} / \mu 1$ in control group, whereas the different doses of $A$. brasiliana and A. bettzickiana leaf extract treated groups showed RBC count that varies between $5.310^{12} / \mu \mathrm{l}$ to $5.810^{12} / \mu 1$. The symptoms of anemia occur due to a decrease in the level of hemoglobin (Ojezele et al., 2013). Packed cell volume (PCV) was denoted as the proportion of blood volume that was occupied by red blood cells. Along with hemoglobin concentration, white blood cell count and platelet count, an integral part of a person's complete blood count was PCV (Purves et al., 2004). The detection of PCV is a simple and reliable method for detecting the presence or absence of anemia or polycythemia.

There was no significant difference in RBC profile following treatment with different doses of leaf extracts of $A$. brasiliana and $A$. bettzickiana. This result indicated that the administration of Alternanthera leaf extracts does not affect erythropoiesis, had no effect on morphology or does not induce osmotic fragility of red blood cells (Odeyemi et al., 2009). The level of packed cell volume was not altered significantly in the different group of mice studied. The above results showed the non-toxic nature of the $A$. brasiliana and $A$. bettzickiana extracts which does not induce any anemia and no significant difference in the level of hemoglobin, RBC and packed cell volume in different doses of leaf extract treated mice.

The level of WBC was found to be $7.510^{3} / \mu 1$ in control group and the level was found to vary between 7 to $7.610^{3} / \mu \mathrm{l}$ in different doses of Alternanthera leaf extract treated mice groups. The first line of cellular defense that responds to inflammation, infectious agents or tissue injury is WBC. In sub-acute toxicity studies, an increase in the level of WBC results from the effect of herbal extracts in inducing the immune response of treated animals (Tousson et al., 2011). On the other hand, a significant 
decrease in WBC count indicated a decrease in the production of leukocytes called leukopenia, a condition that reflects the less ability of the body to fight off infections. However, in the present work, the hematological analysis revealed that the estimated total WBC count after administration of various doses of Alternanthera leaf extracts was not significantly changed when compared to the control. This result may confirm that the hydroethanol leaf extracts used in this study do not possess any chemicals capable of inducing leukocytosis or leukopenia (Weingand et al., 1996).

Table 2: Hematological profile of control and different doses of A. brasiliana and A. bettzickiana extract treated groups.

\begin{tabular}{|c|c|c|c|c|c|}
\hline Groups & $\mathrm{Hb}(\mathrm{g} \%)$ & PCV $(\%)$ & $\operatorname{RBC}(1012 / \mu \mathrm{l})$ & WBC $(103 / \mu \mathrm{l})$ & Platelets $(109 / \mu \mathrm{l})$ \\
\hline Group I (Control) & $14.6 \pm 0.11$ & $43.9 \pm 0.34$ & $5.6 \pm 0.15$ & $7.5 \pm 0.10$ & $6.2 \pm 0.05$ \\
\hline Group II (100 mg/kg bw) & $14.6 \pm 0.06^{\mathrm{ns}}$ & $43.7 \pm 0.1^{\mathrm{ns}}$ & $5.7 \pm 0.1^{\mathrm{ns}}$ & $7.5 \pm 0.21^{\mathrm{ns}}$ & $6.2 \pm 0.06^{\mathrm{ns}}$ \\
\hline Group III (250 mg/kg bw) & $14.6 \pm 0.17^{\mathrm{ns}}$ & $43.8 \pm 0.31^{\mathrm{ns}}$ & $5.8 \pm 0.35^{\mathrm{ns}}$ & $7.5 \pm 0.3^{\text {ns }}$ & $6.3 \pm 0.15^{\mathrm{ns}}$ \\
\hline Group IV (500 mg/kg bw) & $14.7 \pm 0.25^{\text {ns }}$ & $43.9 \pm 0.06^{\mathrm{ns}}$ & $5.8 \pm 0.15^{\mathrm{ns}}$ & $7.6 \pm 0.25^{\mathrm{ns}}$ & $6.4 \pm 0.25^{\mathrm{ns}}$ \\
\hline Group V (1000 mg/kg bw) & $14.6 \pm 0.32^{\mathrm{ns}}$ & $43.7 \pm 0.40^{\mathrm{ns}}$ & $5.7 \pm 0.15^{\mathrm{ns}}$ & $7.5 \pm 0.20^{\mathrm{ns}}$ & $6.4 \pm 0.06^{\mathrm{ns}}$ \\
\hline Group VI (2000 mg/kg bw) & $14.0 \pm 0.21^{\mathrm{ns}}$ & $41.7 \pm 0.25^{\text {ns }}$ & $5.3 \pm 0.1^{\mathrm{ns}}$ & $7.0 \pm 0.1^{\mathrm{ns}}$ & $6.2 \pm 0.10^{\mathrm{ns}}$ \\
\hline Group VII (100 mg/kg bw) & $14.6 \pm 0.10^{\mathrm{ns}}$ & $43.8 \pm 0.30^{\mathrm{ns}}$ & $5.8 \pm 0.00^{\mathrm{ns}}$ & $7.4 \pm 0.05^{\mathrm{ns}}$ & $6.3 \pm 0.05^{\mathrm{ns}}$ \\
\hline GroupVIII (250 mg/kg bw) & $14.6 \pm 0.11^{\mathrm{ns}}$ & $43.9 \pm 0.34^{\mathrm{ns}}$ & $5.8 \pm 0.00^{\mathrm{ns}}$ & $7.4 \pm 0.11^{\mathrm{ns}}$ & $6.4 \pm 0.00^{\mathrm{ns}}$ \\
\hline Group IX (500 mg/kg bw) & $14.6 \pm 0.05^{\mathrm{ns}}$ & $44 \pm 0.17^{\mathrm{ns}}$ & $5.8 \pm 0.05^{\mathrm{ns}}$ & $7.56 \pm 0.05^{\mathrm{ns}}$ & $6.5 \pm 0.10^{\mathrm{ns}}$ \\
\hline Group X (1000 mg/kg bw) & $14.5 \pm 0.10^{\mathrm{ns}}$ & $43.5 \pm 0.30^{\mathrm{ns}}$ & $5.7 \pm 0.05^{\mathrm{ns}}$ & $7.3 \pm 0.05^{\mathrm{ns}}$ & $6.4 \pm 0.05^{\mathrm{ns}}$ \\
\hline Group XI (2000 mg/kg bw) & $14.0 \pm 0.21^{\mathrm{ns}}$ & $42.00 \pm 0.60^{\mathrm{ns}}$ & $5.4 \pm 0.05^{\mathrm{ns}}$ & $7.1 \pm 0.05^{\mathrm{ns}}$ & $6.2 \pm 0.05^{\mathrm{ns}}$ \\
\hline
\end{tabular}

Values are expressed as mean $\pm \mathrm{SD}$ of three mice in each group.

Statistical comparison: Group II, III, IV, V,VI, VII, VIII,IX, X and XI vs. Group I.

ns - not significant at $5 \%(p<0.05)$.

The platelet count was found to be $6.210^{\%} / \mu \mathrm{L}$ in the control group. This count alternate between $6.210^{9 /} \mu \mathrm{L}$ to $6.510^{9} /$ $\mu \mathrm{L}$ in the different doses of Alternanthera leaf extract treated groups. Thrombocytopenia is a condition that reflects abnormally low levels of platelets in circulation. Either a decrease in production or an increase in the destruction of platelets results in thrombocytopenia (Tousson et al., 2011). Platelet destruction may result from the administration of some drugs that provoke platelet antibodies, resulting in thrombocytopenia (Weingand et al., 1996). An abnormal increase in the number of circulating platelets is known as thrombocytosis (Aajibade et al., 2012). However, in this study, mice treated with different doses of Alternanthera leaf extracts showed nonsignificant alteration in platelets count when compared to control mice. This results showed that the hydroethanolic leaf extracts of Alternanthera does not affect platelet levels as it exhibited no significant effect in inducing neither thrombocytopenia nor thrombocytosis.

One of the most sensitive targets of toxic compounds in humans and animals are the hematopoietic system that serves as an important index for reflecting physiological and pathological condition. The various hematological parameters estimated in this study showed no significant difference $(P>0.05)$ in the Alternanthera extract treated groups when compared to control group. The inertness of the Alternanthera leaf extracts on this organ was evident from the above hematological analysis. Hence, the selected Alternanthera leaf extracts may not have any harmful effects on bone marrow function. This justifies the fact that at all doses of $A$. brasiliana and $A$. bettzickiana used in this study does not induce any significant alterations in hematological profile, making it safe for therapeutic applications.

\section{Liver histopathology}

Histopathological investigations were carried out to find out any damage and changes in the liver morphology in control mice and in mice groups following treatment with Alternanthera leaf extracts (Figure 1 and 2). Sub-acute toxicity studies on different doses of $A$. brasiliana and A. bettzickiana leaf extracts showed no discrete pathological changes in the liver tissue of swiss albino mice in doses below $1000 \mathrm{mg} / \mathrm{kg}$ b.wt. Group-I, normal control groups showed the normal architecture of the central vein, hepatocytes, sinusoids and vacuoles. Group-II, group-III, group-IV, groupVII, group-VIII and group-IX mice showed normal architecture compared with control group in which hepatocytes are distinct and relatively normal, no fatty changes, dilation of blood vessels and necrosis were observed. But treatment with Alternanthera leaf extracts at the concentration of 1000 and $2000 \mathrm{mg} / \mathrm{kg}$ of bwt, the treated mice (group-V, group-VI, group-X and group-XI) showed some damages like mild inflammation of hepatocytes, mild periportal inflammation, expanded vacuoles and mild alteration in the central vein structure.

Hydroethanolic extracts of both leaves to the dose range of below $1000 \mathrm{mg} / \mathrm{kg}$ bwt does not produced any histopathological changes in the liver architecture of treated mice. But the mice groups treated with leaf extracts of $1000 \mathrm{mg}$ and $2000 \mathrm{mg} / \mathrm{kg} \mathrm{bwt}$ showed very mild alteration of liver architecture. Being minor, the observed changes are not necessarily an indicator of hepatic damage as a result of the selected leaf extract treatment.

The results of sub-acute toxicity studies on the hydroethanolic leaf extracts of A. brasiliana and A. bettzickiana revealed that up to the administered dose level of $2000 \mathrm{mg} / \mathrm{kg}$ bwt, the extracts do not induce any changes in general appearance 
and behavior. Hematological parameters were not significantly altered. The histopathological investigations also showed that the liver architecture was normal in the dose level of below $1000 \mathrm{mg}$ / $\mathrm{kg}$ bwt, but both plant leaf extracts at the concentration of 1000 and $2000 \mathrm{mg} / \mathrm{kg}$ bwt showed only minor alteration in the liver architecture. So, the hydroethanolic leaf extracts of $A$. brasiliana and $A$. bettzickiana up to the dose of $2000 \mathrm{mg} / \mathrm{kg}$ bwt were found to be safe.

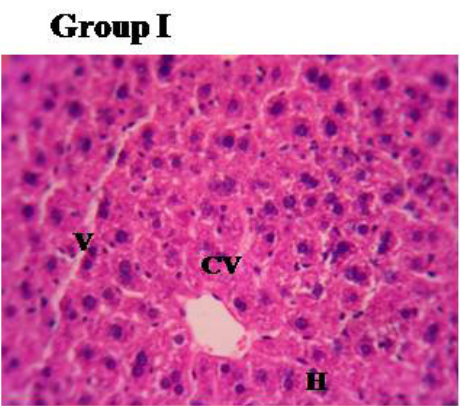

Group IV

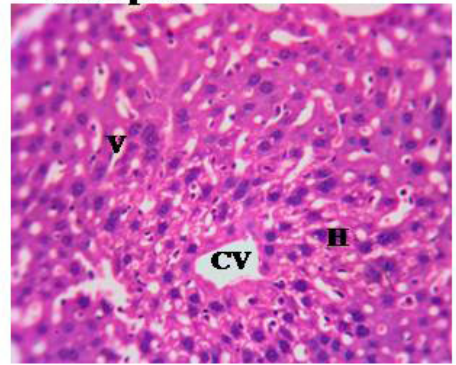

Group II

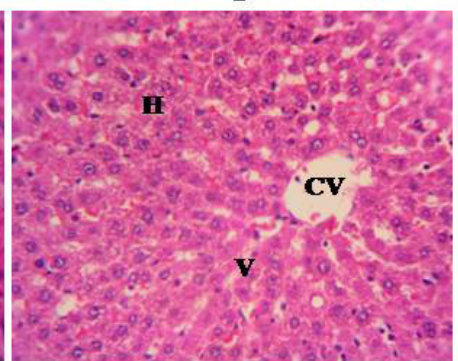

Group V

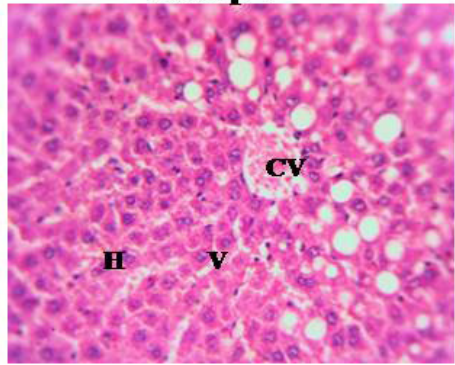

Group III

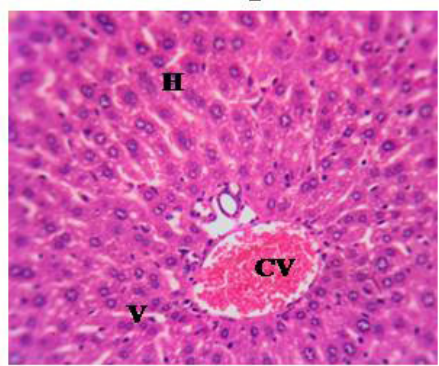

Group VI

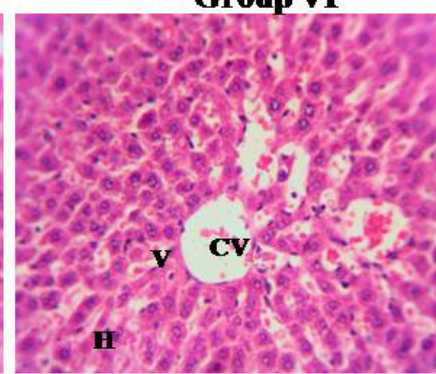

CV-Central Vein V-Vacuoles H-Hepatocytes

Fig. 1: Liver histopathology pattern of $A$. brasiliana leaf extract treated groups.

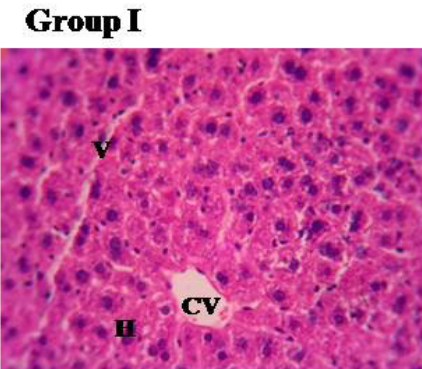

Group IV

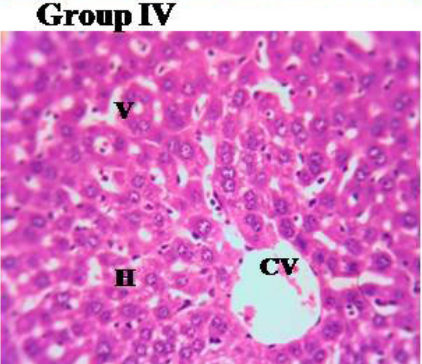

Group II

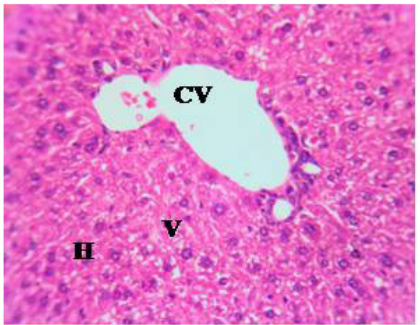

Group V

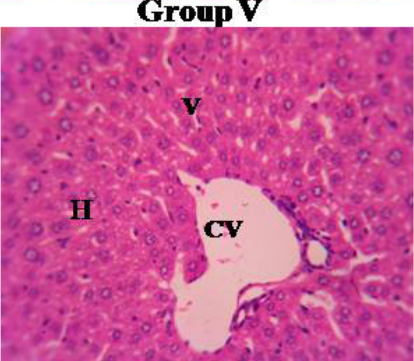

Group III

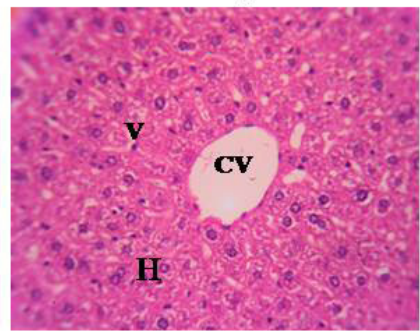

Group VI

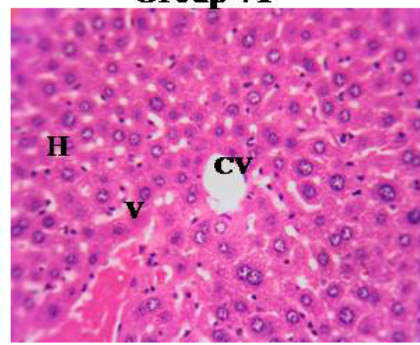

CV-Central Vein V-Vacuoles H-Hepatocytes

Fig. 2: Liver histopathology pattern of $A$. bettzickiana leaf extract treated groups.

\section{In vitro cytotoxic activity}

Cell lines are used as models as they provide a large number of consistent cells for prolonged use. Cell lines are used to provide reliable experimental results as they maintain most cellular characters (Bretagnol et al., 2008). In vitro cytotoxicity screening studies provide important data that helps in the selection of plant extracts with potential antitumor properties for further studies (Cardellina et al., 1999). 
In this study, the in vitro cytotoxic effects of hydroethanolic leaf extracts of $A$. brasiliana and A. bettzickiana versus DLA cell line was determined by MTT assay (Table 3). It was observed that there was an increase in cytotoxicity with an increase in the concentration of both leaf extracts. At $12.5 \mu \mathrm{g} / \mathrm{ml}$ concentration, A. brasiliana and A. bettzickiana produced $2.66 \%$ and $3.14 \%$ cell death, whereas at high concentration $(200 \mu \mathrm{g} / \mathrm{ml})$, $50.42 \%$ and $53.51 \%$ cell death were observed with an $\mathrm{IC}_{50}$ value of $192.20 \mu \mathrm{g} / \mathrm{ml}$ and $157.25 \mu \mathrm{g} / \mathrm{ml}$ respectively. This result revealed that $A$. bettzickiana extract was more potent than $A$. brasiliana extract in causing toxicity and death of DLA cell line.

Table 3: In vitro cytotoxic effects of hydroethanolic leaf extracts of $A$. brasiliana and $A$. bettzickiana versus DLA cell line.

\begin{tabular}{ccc}
\hline Conc $(\boldsymbol{\mu g} / \mathbf{m l})$ & \multicolumn{2}{c}{$\%$ Cell Inhibition } \\
\hline & A. brasiliana & A. bettzickiana \\
\hline 12.5 & 2.66 & 3.14 \\
25 & 14.15 & 15.11 \\
50 & 20.56 & 22.61 \\
100 & 35.91 & 38.27 \\
200 & 50.42 & 53.51 \\
\hline
\end{tabular}

$\mathrm{IC}_{50}$ Values: A. brasiliana: $192.20 \mu \mathrm{g} / \mathrm{ml}$. A. bettzickiana: $157.25 \mu \mathrm{g} / \mathrm{ml}$.

In the management and control of cancer, natural products identified from plants have played a major role. In a 2000 based worldwide sales, products from medicinal plants constitute 14 of top 35 drugs (Butlet, 2004). With more than $2,70,000$ higher plants existing on this planet, only a small portion of plants has been studied phytochemically. So, it is evident that plants can serve as a source of potential bioactive compounds for the development of new 'leads' to combat cancer (Shoeb, 2006). The natural products from plants such as alkaloids, flavonoids, terpenes, phenols, etc., had received wide attention because of their diverse pharmacological properties including cytotoxic and cancer chemopreventive potentials (Babu et al., 2002). Our previous work revealed the presence of secondary metabolites in the hydroethanolic leaf extracts of $A$. brasiliana and $A$. bettzickiana. Those secondary metabolites present in Alternanthera may be responsible for their cytotoxic activity on DLA cell line.

\section{CONCLUSION}

For the control and treatment of many ailments, there has been a growing interest in the study of therapeutic potentials of natural products derived from plants. In the present work, the results of in vivo sub-acute toxicity study clearly showed the nontoxic nature of hydroethanolic leaf extracts of $A$. brasiliana and $A$. bettzickiana up to the tested dose level of $2000 \mathrm{mg} / \mathrm{kg}$ bwt. The $\mathrm{LD}_{50}$ values of both leaf extracts were considered to be more than $2000 \mathrm{mg} / \mathrm{kg}$ bwt. The in vitro MTT assay revealed the toxic potential of the leaf extracts on DLA tumor cells. It was concluded that further antitumor studies in in vivo animal models are necessary in order to establish the potential of $A$. brasiliana and $A$. bettzickiana as a source for new anticancer medicine.

\section{ACKNOWLEDGMENT}

We are thankful to the Management of PSG College of
Arts and Science, Coimbatore, for providing with all the facilities required to carry out this work.

\section{AUTHORS' CONTRIBUTIONS}

Mrs. Kasthuri O $\mathrm{R}$ contributed in performing the experiment, data compilation and wrote the first draft of the manuscript. Dr. Ramesh B involved in corrections in the manuscript and overall management of the study.

\section{CONFLICT OF INTEREST}

We, the authors confirm that we have no conflict of interest in this article content.

\section{FUNDING SOURCES}

No funding support received for this study.

\section{REFERENCES}

Kaufman D, Chabner BA. Clinical strategies for cancer treatment: The role of drugs. In: Chabner BA, Longo DL, editors. Cancer Chemotherapy and Biotherapy: Principles and Practice. Philadelphia: Lippincott-Raven 1996; 1-16.

Lemkebthomas L, Williams DA, Roche VF, William ZS. Foye's principles of medicinal chemistry., 6th edition, 2008; 1147-8.

Moongkarndi P, Kosem N, Kaslungka S, Luanratana O, Pongpan N, Neungton N. Antiproliferation, antioxidation and induction of apoptosis by Garcinia mangostana (mangosteen) on SKBR3 human breast cancer cell line. J Ethnopharmacol, 2004; 90:161-6.

Kinzler KW, Vogelstein B. Introduction. The Genetic Basis of Human Cancer. 2nd ed. New York: McGraw-Hill Publishers; 2002.

Newman DJ, Cragg GM, Snader KM. Natural Products as Sources of New Drugs. J Nat Prod, 2003; 66:1022-103.

Liu WJ. Introduction to traditional herbal medicines and their study. In: Liu JH, editor. Traditional Herbal Medicine Research Methods. New Jersey: John Wiley \& Sons, Inc; 2011; 1-26.

Lopes LDC, Albano F, F Laranja F, Alves LM and Silva LFM, et al. Toxicological evaluation by in vitro and in vivo assays of an aqueous extract prepared from Echinodorus macrophyllus leaves. Toxicol Lett, 2000; 116:189-98.

Saad B, Azaizeh H, Abu-Hijleh G, Said S. Safety of traditional Arab herbal medicine. Evidence-Based Complement Altern Med, 2006; 3:433-9.

Wojcikowski K, Johnson DW, Gobé G. Medicinal herbal extracts - renal friend or foe? Part one: The toxicities of medicinal herbs. Nephrology (Carlton), 2004; 9:313-8.

Anisuzzaman ASM, Sugimoto N, Sadik G, Gafur MA. Subacute toxicity study of 5-Hydroxy-2(Hydroxy-Methyl) 4H-pyran-4 One, isolated from Aspergillus fumigatus. Pak J Biol Sci, 2001; 4:1012-5.

Rang HP, Dale M, Ritter. Pharmacology. Volume 13. 4th Ed. New York, NY, USA; Churchill Livingstone, 2001.

Hussien M Alwadie. Morphology and Distribution of Three Genera of Amaranthaceae in the South Western Area of Saudi Arabia. J King Saud Univ, 2005; 18(1):51-62.

Kumar S, Singh P, Mishra G, Srivasta S, Jha KK, Khosa RL. Phytopharmacological review of Alternanthera brasiliana (Amaranthaceae). Asian J Plant Sci Res, 2011; 1:41-7.

Suphanthip P, Waranya C, Orawan M, Pradit P, Kanokwan J Alternanthera sessilis and Alternanthera bettzickiana Improved Superoxide Dismutase and Catalase Activities in the Livers of Ovariectomized Mice. Journal of Applied Biopharmaceutics and Pharmacokinetic, 2013; 1(2):6471.

Kasthuri OR and Ramesh B. Phytochemical screening and in vitro antioxidant activities of leaf extracts of Alternanthera brasiliana (L.) Kuntze and Alternanthera bettzickiana Regel. Asian J Pharm Clin Res, 2018; 11(6):266-272. 
Jonsson M, Jestoi M, Nathanail AV, Kokkonen UM, Anttila M, Koivisto P, Karhunen P, Peltonen K. Application of OECD Guideline 423 in assessing the acute oral toxicity of moniliformin. Food Chem Toxicol, 2013; 53:27-32.

Mosmann T. Rapid colorimetric assay for cellular growth and survival: application to proliferation and cytotoxicity assays. Journal of Immunological Methods, 1983; 65:55-63.

Wilson AP, John RW. Animal cell culture: a practical approach. oxford: Oxford University Press, 2000.

Yan-Wei H, Chun-Yu L, Chong-Min D, Wen-Qian W, Zhen-Lun G. Induction of apoptosis in human hepatocarcinoma SMMC-7721 cells in vitro by flavonoids from Astragalus complanatus. J Ethnopharmacol, 2009; 123:293-301.

Gesler WM. Therapeutic landscapes: Medical issues in light of the new cultural geography. Soc Sci Med, 1992; 34:735-46.

Bent S, Ko R. Commonly used herbal medicine in the United States: A review. Am J Med, 2004; 116:478-85.

Hunter P. A toxic brew we cannot live without. EMBO Rep, 2008; 9(1):15-8.

Schulz V, Hansel R, Tyler VE. Rational Phytotherapy: A Physician's Guide to Herbal Medicine; Psychology Press: London, UK, 2001.

Akhila JS, Deepa S, Alwar MC. Acute toxicity studies and determination of median lethal dose. Current Sci, 2007; 93:917-20.

Parra AL, Yhebra RS, Sardinas IG, Buela LI. Comparative study of the assay of Artemia salina L. and the estimate of the medium lethal dose (LD50 value) in mice, to determine oral acute toxicity of plant extracts. Phytomedicine, 2001; 8:395-400.

Rosenthal N, Brown S. The mouse ascending: perspectives for human-disease models. Nat Cell Biol, 2007; 9:993-9.

Ahmad M, Lim CP, Akowuah GA, Ismail NN, Hashim MA, Hor SY, Ang LF and Yam MF. Safety assessment of standardised methanol extract of Cinnamomum burmannii. Phytomedicine, 2013; 15:1124-30.

Subramanion LJ, Zakaria Z, Chen Y, Lau YL, Latha LY, Sasidharan S. Acute oral toxicity of methanolic seed extract of cassia fistula in mice. Molecules, 2011; 16(6):5268-82. 106:497-503

Walum E. Acute oral toxicity. Environ Health Perspect 1998;

Klaassen CD. Casarett and Doulls. Toxicology: The Basic Science of Poison. 6th Edn., The McGraw-Hill Companies Inc., New York. 2001.

Nair R, Shukla V, Chanda S. Effect of single dose administration of Polyalthia longifolia (Sonn.) Thw. Var. pendula leaf on gross behavioral assessment in mice. Indian Drugs, 2009; 46:116-23.

Jothy SL, Zuraini Z, Sasidharan S. Phytochemicals screening, DPPH free radical scavenging and xanthine oxidase inhibitiory activities of Cassia fistula seeds extract. J Med Plants Res, 2011; 5(10):1941-7.

Yamthe L, Fokou P, Mbouna C, Keumoe R, Ndjakou B, Djouonzo P, Boyom F. Extracts from Annona Muricata L. and Annona Reticulata L. (Annonaceae) potently and selectively inhibit Plasmodium falciparum. Medicines, 2015; 2(2):55-66.

Schalm OW, Jain NC, Carrol EJ. Veterinary Haematology. 3rd Edn., Lea and Febiger Publication, Philadelphia,1975; 807.

Ajagbonna OP, Onifade KI, Suleiman U. Haematological and biochemical changes in rats given extract of Calotropis procera Sokoto. J Vet Sci, 1999; 1:36-42.

Bosco AD, Gerencser Z, Szendro Z, Ugnai C, Cullere M, et al. Dietary supplementation of spirulina (Arthrospira platensis) and Hyme
Hymus vulgaris) on rabbit meat appearance, oxidative stability and fatty acid profile during retail display. Meat Sci, 2014; 96:114-9.

Raza M, Al-Shabanah OA, El-Hadiyah TM, Al-Majed AA Effect of prolonged vigabatrin treatment on haematological and biochemical parameters in plasma, liver and kidney of Swiss albino mice. Pharmace Scien, 2002; 70:135-45.

Olson H, Betton G, Robinson D, et al. Concordance of the toxicity of pharmaceuticals in humans and in animals. Regulatory Toxicology and Pharmacology, 2000; 32(1):56-67.

Hoffbrand AV, Pettit JE. Essential of Heamatology 3rd edition, Blackwell Sci Inc., USA, 1997.

Jain N, Sharma P, Sharma N, Joshi SC. Haemato-biochemical profile following sub acute toxicity of malathion in male albino rats. Avicenna J Phytomed, 2009; 2:500-506.

Ojezele, Matthew Obaineh, Agunbiade, Shadrach. Phytochemical constituents and medicinal properties of different extracts of Anacardium occidentale and Psidium Guajava. Asian Journal of Biomedical and Pharmaceutical Sciences, 2013; 3(16):20-23.

Purves WK, David S, Gordon HO, Craig HH. Life: The Science of Biology. 7th edition, Mass: Sinauer Associates, Sunderland, 2004; pp: 954

Odeyemi OO, Yakubu MT, Masika PJ, Afolayan AJ Toxicological evaluation of the essential oil from Menthalongifolia L. subsp. capensis leaves in rats. J Med Food, 2009; 12:669-74.

Tousson E, El-Moghazy M, El-Atrsh E. The possible effect of diets containing Nigella sativa and Thymus vulgarison blood parameters and some organs structure in rabbit. Toxicol Ind Health, 2011; 27(2);10716.

Weingand K, Brown G, Hall R, Davies D, Gossett K, et al. Harmonization of animal clinical pathology testing in toxicity and safety studies. The Joint Scientific Committee for International Harmonization of Clinical Pathology Testing. Fundam Appl Toxicol, 1996; 29(2):198-201.

Ajibade TO, Olayemi FO, Arowolo ROA. The haematological and biochemical effects of methanol extract of the seeds of Moringa oleifera in rats. J Medic Plants Res, 2012; 6(2):615-21.

Bretagnol $\mathrm{F}$, et al. The effect of sterilization processes on the bioadhesive properties and surface chemistry of a plasma-polymerized polyethylene glycol film: XPS characterization and L929 cell proliferation tests. Acta Biomater, 2008; 4:1745-51.

Cardellina JH, Fuller RW, Gamble WR, Westergaard C, Boswell J, Munro MHG, Currens M, Boyd MP. Evolving strategies for the selection dereplication and prioritization of antitumor and HIV inhibitory natural products extracts. In: Bohlin, L., Bruhn, J.G. (Eds), Bioassay Methods in Natural Product Research and Development. Kluwer Academic Publishers, Dordrecht 1999; pp. 25-36.

Butlet MS. The role of natural product chemistry in drug discovery. J Nat Products, 2004; 67:2141-2153.

Shoeb M. Anticancer agents from medicinal plants. Bang J Pharmacol, 2006; 1:35-41.

Babu BH, Shylesh BS, and Padikkala J. Tumour reducing and anticarcinogenic activity of Acanthus ilicifolius in mice. J Ethno Pharmacol, 2002; 79:27-33.

How to cite this article:

Kasthuri OR, Ramesh B. Toxicity Studies on Leaf Extracts of Alternanthera brasiliana (L.) Kuntze and Alternanthera bettzickiana (Regel) Voss. J App Pharm Sci, 2018; 8(10): 082089. 